\title{
Article \\ Svalbamides A and B, Pyrrolidinone-Bearing Lipodipeptides from Arctic Paenibacillus sp.
}

\author{
Young Eun Du ${ }^{1}$, Eun Seo Bae ${ }^{1}$, Yeonjung Lim ${ }^{2}$, Jang-Cheon $\mathrm{Cho}^{2}$, Sang-Jip Nam ${ }^{3}$, Jongheon Shin ${ }^{1}{ }^{1}$, \\ Sang Kook Lee ${ }^{1}{ }^{\oplus}$, Seung-Il Nam ${ }^{4}$ and Dong-Chan $\mathrm{Oh}^{1, *}$
}

1 Natural Products Research Institute, College of Pharmacy, Seoul National University, Seoul 08826, Korea; dye0302@snu.ac.kr (Y.E.D.); ddol1289@snu.ac.kr (E.S.B.); shinj@snu.ac.kr (J.S.); sklee61@snu.ac.kr (S.K.L.)

2 Department of Biological Sciences, Inha University, Incheon 22212, Korea; yj_lim@inha.edu (Y.L.); chojc@inha.ac.kr (J.-C.C.)

3 Department of Chemistry and Nanoscience, Ewha Womans University, Seoul 03760, Korea; sjnam@ewha.ac.kr

4 Korea Polar Research Institute, Incheon 21990, Korea; sinam@kopri.re.kr

* Correspondence: dongchanoh@snu.ac.kr; Tel.: +82-880-2491; Fax: +82-762-8322

check for updates

Citation: Du, Y.E.; Bae, E.S.; Lim, Y.; Cho, J.-C.; Nam, S.-J.; Shin, J.; Lee,

S.K.; Nam, S.-I.; Oh, D.-C.

Svalbamides A and B,

Pyrrolidinone-Bearing

Lipodipeptides from Arctic

Paenibacillus sp. Mar. Drugs 2021, 19,

229. https://doi.org/10.3390/

md19040229

Academic Editor: Daniela Giordano

Received: 30 March 2021

Accepted: 15 April 2021

Published: 17 April 2021

Publisher's Note: MDPI stays neutral with regard to jurisdictional claims in published maps and institutional affiliations.

Copyright: (c) 2021 by the authors. Licensee MDPI, Basel, Switzerland. This article is an open access article distributed under the terms and conditions of the Creative Commons Attribution (CC BY) license (https:/ / creativecommons.org/licenses/by/ $4.0 /)$.

\begin{abstract}
Two new secondary metabolites, svalbamides A (1) and B (2), were isolated from a culture extract of Paenibacillus sp. SVB7 that was isolated from surface sediment from a core (HH17-1085) taken in the Svalbard archipelago in the Arctic Ocean. The combinational analysis of HR-MS and NMR spectroscopic data revealed the structures of $\mathbf{1}$ and $\mathbf{2}$ as being lipopeptides bearing 3-amino2-pyrrolidinone, D-valine, and 3-hydroxy-8-methyldecanoic acid. The absolute configurations of the amino acid residues in svalbamides A and B were determined using the advanced Marfey's method, in which the hydrolysates of $\mathbf{1}$ and $\mathbf{2}$ were derivatized with L- and D- forms of 1-fluoro2,4-dinitrophenyl-5-alanine amide (FDAA). The absolute configurations of $\mathbf{1}$ and $\mathbf{2}$ were completely assigned by deducing the stereochemistry of 3-hydroxy-8-methyldecanoic acid based on DP4 calculations. Svalbamides A and B induced quinone reductase activity in Hepa1c1c7 murine hepatoma cells, indicating that they represent chemotypes with a potential for functioning as chemopreventive agents.
\end{abstract}

Keywords: Paenibacillus; Arctic; Svalbard; Marfey's method; DP4 calculation; quinone reductase; lipopeptide; 3-amino-2-pyrrolidinone

\section{Introduction}

Marine habitats were generally recognized as extreme environments exposing organisms to conditions of high salt, high pressure, and hypoxia, forcing them to develop unique physiologies in comparison to their terrestrial counterparts. Among the marine organisms, bacteria have always contributed significantly as a source for the discovery of new marine natural products, with 232 new compounds found in 2019 alone [1]. However, most (62.5\%) of the new marine-bacterial molecules were derived from the single genus Streptomyces. We also reported the dimeric benz $[a]$ anthracene thioethers donghaesulfins $A$ and B, and rearranged angucyclinones donghaecyclinones A-C from marine-derived Streptomyces sp. SUD119 in 2019 and 2020, respectively [2,3]. Even though Streptomyces is chemically prolific and still provides numerous new bioactive compounds, the desire for compounds with greater structural diversity has brought about chemical investigations of a wider diversity of bacteria that extend beyond conventional phylogenetically biased chemical studies. The chemical examination of bacteria inhabiting the Arctic Ocean-a more extreme habitat than tropical or subtropical oceans that remains poorly investigated-represents a promising strategy for the discovery of new bioactive molecules.

In our continuing efforts to search for new bioactive microbial compounds from extreme marine environments, we explored the chemistry of bacterial strains from the Arctic Ocean. Our initial chemical profiling of Arctic strains led to the discovery of articoside and 
C-1027 chromophore-V-two new benzoxazine-bearing compounds that inhibit Candida albicans isocitrate lyase-from Streptomyces sp. ART5 collected from the East Siberian continental margin [4]. In this study, we diversified the phylogeny of bacteria for chemical analysis and focused on non-Streptomyces bacterial strains inhabiting the Arctic Ocean. The Paenibacillus sp. SVB7 strain was isolated from sediment collected at the continental shelf (depth $=322 \mathrm{~m}$ ) off Wijdefjorden, Svalbard, during a marine-geoscientific cruise to North Spitsbergen in 2017. Cultivation in liquid media and the LC/MS-based chemical examination of the strain Paenibacillus sp. SVB7 identified the production of previously unreported molecules with the molecular ions at $\mathrm{m} / \mathrm{z} 384$. Scaling-up of the culture enabled us to purify two new compounds, svalbamides A and B, and subsequently elucidate their structures by spectroscopic analysis, chemical derivatization, and quantum mechanicsbased calculation. Here, we report the structural determination of svalbamides A and B (1, 2; Figure 1) along with their biological activity.
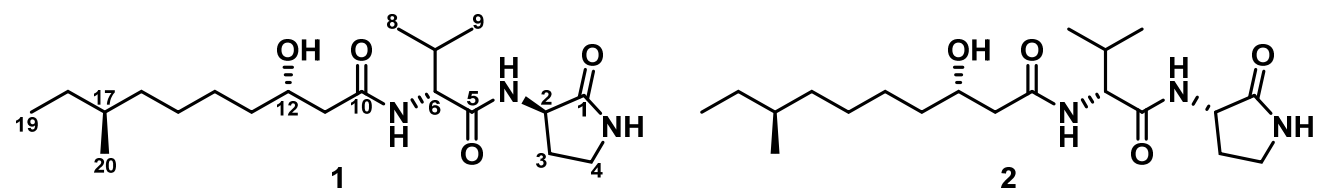

Figure 1. The structures of svalbamides A (1) and B (2).

\section{Results and Discussion}

\subsection{Phylogenetic Analysis}

Sequence comparison using the almost complete 16S rRNA gene sequence of strain SVB7 (1440 bp) in BLASTn and EzBioCloud searches revealed that strain SVB7 belongs to the genus Paenibacillus of the Paenibacillaceae family. According to 16S rRNA gene sequence similarities, strain SVB7 was most closely related to P. maysiensis SX-49 ${ }^{\mathrm{T}}(99.30 \%$ similarity), followed by P. terrae AM141 ${ }^{\mathrm{T}}(98.26 \%)$, and P. peoriae DSM $8320^{\mathrm{T}}(97.42 \%)$. In all phylogenetic trees inferred by maximum likelihood, neighbor-joining, and minimumevolution methods, strain SVB7 was located within the Paenibacillus clade and formed a robust clade with $P$. maysiensis and $P$. terrae, providing clear support for its genus being classified as Paenibacillus (Figure 2). Based on the formation of the robust clade with $P$. maysiensis $\mathrm{SX}-49^{\mathrm{T}}$ and $>98.7 \%$ 16S rRNA gene sequence similarity, it is likely that strain SVB7 is a member of Paenibacillus maysiensis. However, inclusion of strain SVB7 must be confirmed using whole-genome sequencing analysis.

\subsection{Structural Elucidation}

Svalbamide A (1) was isolated as a white powder. The molecular formula of $\mathbf{1}$ was assigned as $\mathrm{C}_{20} \mathrm{H}_{37} \mathrm{~N}_{3} \mathrm{O}_{4}$, which has an unsaturation number of 4 based on high-resolution electrospray ionization (HR-ESI) mass spectrometry $\left([\mathrm{M}+\mathrm{H}]^{+}\right.$at $m / z 384.2851$, calculated as 384.2857) along with ${ }^{1} \mathrm{H}$ and ${ }^{13} \mathrm{C}$ NMR spectra. The ${ }^{13} \mathrm{C}$ NMR spectra of 1 showed three carbonyl carbon $\left(\delta_{\mathrm{C}} 174.2,171.0\right.$, and 170.8), one oxygenated methine carbon $\left(\delta_{\mathrm{C}} 67.5\right)$, and two $\alpha$-amino methine carbon $\left(\delta_{\mathrm{C}} 57.2\right.$ and 49.4$)$ signals. Further analysis of these spectra revealed the existence of eight methylene carbon resonances $\left(\delta_{C} 43.4-25.2\right)$, two more methine carbons $\left(\delta_{C} 33.7\right.$ and 30.7$)$, and four methyl carbons $\left(\delta_{C} 19.3,19.1,18.0\right.$, and 11.2) in the aliphatic region. The ${ }^{1} \mathrm{H}$ and HSQC NMR spectra of 1 identified four exchangeable protons $\left(\delta_{\mathrm{H}} 8.10,7.83,7.78\right.$, and 4.65$)$, one carbinol proton $\left(\delta_{\mathrm{H}} 3.78\right)$, two $\alpha$-amino protons $\left(\delta_{\mathrm{H}} 4.30\right.$ and 4.18$)$, two more methine protons $\left(\delta_{\mathrm{H}} 1.96\right.$ and 1.28$)$, eight methylene protons $\left(\delta_{\mathrm{H}} 1.05-3.16\right)$, and twelve methyl protons $\left(\delta_{\mathrm{C}} 0.88,0.84,0.82\right.$, and 0.81$)$. Based on the NMR spectroscopic features of the amide carbonyl carbons, $\alpha$-amino groups, and many aliphatic signals, the structure of svalbamide A (1) was deduced as a peptide bearing an aliphatic chain. 


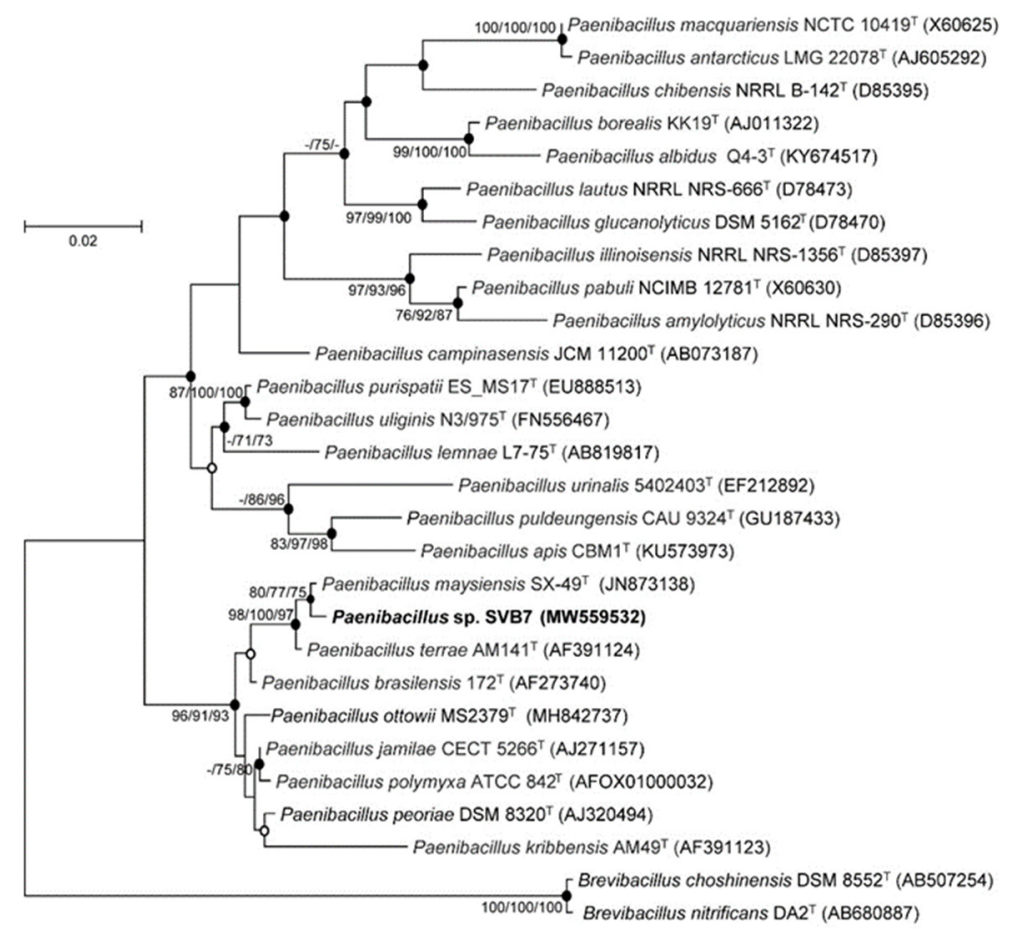

Figure 2. Maximum likelihood phylogenetic tree showing the position of Paenibacillus sp. SVB7. Bootstrap values (expressed as percentages of 1000 replications) over $70 \%$ are shown to the left of the node, and represent maximum likelihood, neighbor-joining, and minimum evolution (reading from left to right). Filled and open circles at each node indicate nodes recovered by all three treeing methods or by two treeing methods, respectively. Two 16S rRNA gene sequences of the genus Brevibacillus were used as outgroups. Bar, 0.02 substitutions per nucleotide position.

The interpretation of COSY, TOCSY, and HMBC NMR spectra enabled us to determine the partial structures of 1 . First, the $2-\mathrm{NH}\left(\delta_{\mathrm{H}} 8.10\right) / \mathrm{H}-2\left(\delta_{\mathrm{H}} 4.30\right)$ COSY correlation connected $2-\mathrm{NH}$ to the $\mathrm{C}-2 \alpha$-carbon $\left(\delta_{\mathrm{C}} 49.4\right)$. The TOCSY and COSY correlations among $\mathrm{H}-2, \mathrm{H}-3 \mathrm{a}$ and $\mathrm{H}-3 \mathrm{~b}\left(\delta_{\mathrm{H}} 1.82\right.$ and 2.26$), \mathrm{H}_{2}-4\left(\delta_{\mathrm{H}} 3.16\right)$, and $4-\mathrm{NH}\left(\delta_{\mathrm{H}} 7.78\right)$ secured the spin system from $2-\mathrm{NH}$ to $4-\mathrm{NH}$. The HMBC correlations from $4-\mathrm{NH}$ to $\mathrm{C}-1\left(\delta_{\mathrm{C}} 174.2\right), \mathrm{C}-2\left(\delta_{\mathrm{C}}\right.$ $49.4), \mathrm{C}-3\left(\delta_{\mathrm{C}} 28.0\right)$, and $\mathrm{C}-4\left(\delta_{\mathrm{C}} 38.0\right)$, and from $2-\mathrm{NH}$ to $\mathrm{C}-1\left(\delta_{\mathrm{C}} 174.2\right)$, led to elucidation of the substructure as a 3-amino-2-pyrrolidinone. The structure of valine was assigned based on the ${ }^{1} \mathrm{H}-{ }^{1} \mathrm{H}$ couplings of 6- $\mathrm{NH}\left(\delta_{\mathrm{H}} 7.83\right), \mathrm{H}-6\left(\delta_{\mathrm{H}} 4.18\right), \mathrm{H}-7\left(\delta_{\mathrm{H}} 1.96\right), \mathrm{H}_{3}-8\left(\delta_{\mathrm{H}} 0.84\right)$, and $\mathrm{H}_{3}-9\left(\delta_{\mathrm{H}} 0.88\right)$ in the COSY and TOCSY NMR spectra along with the H-6/C-5 $\left(\delta_{\mathrm{C}} 171.0\right)$ HMBC correlation. The remaining part of the molecule was composed of a lipophilic acyl chain. The protons in the substructure from C-11 to C-20 belong to a single spin system as revealed by COSY / TOCSY correlations of the protons. These protons showed correlation peaks with an exchangeable proton at $\delta_{\mathrm{H}} 4.65$ in the TOCSY spectrum, indicating that the exchangeable proton is also included in the spin system (Figure 3 ).

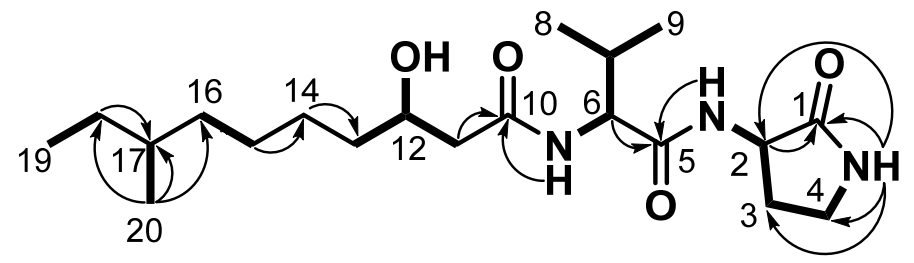

Figure 3. Key HMBC and COSY correlations of svalbamides A (1) and B (2).

The COSY correlation of $\mathrm{H}-11 \mathrm{a}$ and $\mathrm{H}-11 \mathrm{~b}\left(\delta_{\mathrm{H}} 2.23\right.$ and 2.29$) / \mathrm{H}-12\left(\delta_{\mathrm{H}} 3.78\right), \mathrm{H}-$ $12 / \mathrm{H}_{2}-13\left(\delta_{\mathrm{H}} 1.33\right)$, and $\mathrm{H}-12 / 12-\mathrm{OH}\left(\delta_{\mathrm{H}} 4.65\right)$ showed connectivity from C-11 to C-13, including $12-\mathrm{OH}$. The HMBC correlations of $12-\mathrm{OH}\left(\delta_{\mathrm{H}} 4.65\right)$ to $\mathrm{C}-11\left(\delta_{\mathrm{C}} 43.4\right), \mathrm{C}-12\left(\delta_{\mathrm{C}}\right.$ 
67.5), and $\mathrm{C}-13\left(\delta_{\mathrm{C}} 36.7\right)$ confirmed the partial structure. $\mathrm{C}-11$ was attached to the $\mathrm{C}-10$ carbonyl carbon as inferred by the H-11a and H-11b/C-10 HMBC correlation. Due to the overlapping aliphatic signals from $\mathrm{H}_{2}-13$ to $\mathrm{H}-18 \mathrm{a}$ and $\mathrm{H}-18 \mathrm{~b}, \mathrm{HMBC}$ correlations played a pivotal role in identifying the planar structure of this linear section. The HMBC correlations from $\mathrm{H}-14 \mathrm{a}$ and $\mathrm{H}-14 \mathrm{~b}\left(\delta_{\mathrm{H}} 1.24\right.$ and 1.34$)$ to $\mathrm{C}-13\left(\delta_{\mathrm{C}} 36.7\right)$, from $\mathrm{H}_{2}-15\left(\delta_{\mathrm{H}} 1.23\right)$ to $\mathrm{C}-14\left(\delta_{\mathrm{C}} 25.2\right)$, and from $\mathrm{H}-16 \mathrm{a}$ and $\mathrm{H}-16 \mathrm{~b}\left(\delta_{\mathrm{H}} 1.05\right.$ and 1.25$)$ to $\mathrm{C}-15\left(\delta_{\mathrm{C}} 26.5\right)$ revealed the connectivity from $\mathrm{C}-13$ to $\mathrm{C}-16$. In addition, the COSY ${ }^{1} \mathrm{H}-{ }^{1} \mathrm{H}$ couplings of $\mathrm{H}-17\left(\delta_{\mathrm{H}}\right.$ 1.28) $/ \mathrm{H}_{3}-20\left(\delta_{\mathrm{H}} 0.81\right)$ and $\mathrm{H}-18 \mathrm{a}$ and $\mathrm{H}-18 \mathrm{~b}\left(\delta_{\mathrm{H}} 1.09\right.$ and 1.28$) / \mathrm{H}_{3}-19\left(\delta_{\mathrm{H}} 0.82\right)$, along with the HMBC signals of $\mathrm{H}_{3}-20\left(\delta_{\mathrm{H}} 0.81\right)$ to $\mathrm{C}-16\left(\delta_{\mathrm{C}} 36.0\right), \mathrm{C}-17\left(\delta_{\mathrm{C}} 33.7\right)$, and $\mathrm{C}-18\left(\delta_{\mathrm{C}} 28.9\right)$, were finally assigned to 3-hydroxy-8-methyldecanoic acid (Figure 3). Consequently, the four unsaturation equivalents were fully explained by one pyrrolidinone ring containing one carbonyl group and two more carbonyl functional groups. Thus, svalbamide A (1) must not possess an additional ring and comprises a combination of the three substructures as a linear molecule.

Once the partial structures of 3-amino-2-pyrrolidinone, valine, and 3-hydroxy-8methyldecanoic acid were identified, they were assembled according to the HMBC correlations: $2-\mathrm{NH}\left(\delta_{\mathrm{H}} 8.10\right)$ of pyrrolidinone was correlated with the amide carbonyl carbon $\mathrm{C}-5\left(\delta_{\mathrm{C}} 171.0\right)$ belonging to the valine residue, connecting 3-amino-2-pyrrolidinone to valine. The HMBC correlation from $6-\mathrm{NH}\left(\delta_{\mathrm{H}} 7.83\right)$ of valine to the carbonyl carbon C-10 $\left(\delta_{\mathrm{C}} 170.8\right)$ of 3-hydroxy-8-methyldecanoic acid established the sequence from valine to 3-hydroxy-8-methyldecanoic acid. Therefore, the planar structure of svalbamide A (1) was finally elucidated as a previously unreported lipodipeptide (Figure 3).

Svalbamide B (2) was isolated as a white powder, and its molecular formula was determined to be $\mathrm{C}_{20} \mathrm{H}_{37} \mathrm{~N}_{3} \mathrm{O}_{4}$, which contains four double bond equivalents, using highresolution electrospray ionization (HR-ESI) mass spectrometry $\left([\mathrm{M}+\mathrm{H}]^{+}\right.$at $m / z 384.2845$, calculated as 384.2857). This molecular formula was identical to that of svalbamide A (1). The ${ }^{1} \mathrm{H}$ and ${ }^{13} \mathrm{C}$ NMR data of $\mathbf{2}$ in DMSO- $d_{6}$ were extremely similar to those of $\mathbf{1}$ (Table 1), but distinct differences in chemical shifts were found mainly in the 3-amino-2pyrrolidinone unit. Specifically, H-2 in $\mathbf{1}\left(\delta_{\mathrm{H}} 4.30\right)$ was shifted upfield in $2\left(\delta_{\mathrm{H}} 4.27\right)$, while signals for $\mathrm{H}-3 \mathrm{a}$ and $\mathrm{H}-3 \mathrm{~b}$ in 1 , at $\delta_{\mathrm{H}} 1.82$ and 2.26, were detected at $\delta_{\mathrm{H}} 1.76$ and 2.29 in 2. C-3 $\left(\delta_{\mathrm{C}} 28.0\right)$ also shifted slightly to the deshielded region by $0.3 \mathrm{ppm}$ in svalbamide $\mathrm{B}$ (2). Comprehensive analysis of $1 \mathrm{D}$ and 2D NMR data indicated the planar structure of 2 to be the same as 1 (Figure 3). Based on the observation that the distinct chemical shift differences were found in 3-amino-2-pyrrolidone unit, the structure of svalbamide B (2) was expected to have stereochemical modification in this residue.

The absolute configurations at the $\alpha$-carbons of the two amino acid units were determined by applying the advanced Marfey's method for derivatization with the L- and Dforms of 1-fluoro-2,4-dinitrophenyl-5-alanine amide (FDAA). LC/MS analysis of the FDAA derivatives of hydrolysates of $\mathbf{1}$ and $\mathbf{2}$ (Table S1) showed that they commonly possess D-valine. Because 3-amino-2-pyrrolidinone is converted into 2,4-diaminobutanoic acid during acid hydrolysis, an authentic sample of $2 S, 4$-diaminobutanoic acid was derivatized with L- and D-FDAA to allow comparison. By comparing the retention times of the FDAA adducts of authentic $2 S$,4-diaminobutanoic acid, svalbamide A (1) was revealed to bear 3R-3-amino-2-pyrrolidinone, whereas svalbamide B (2) incorporates 3S-3-amino-2pyrrolidinone (Figure 1).

The 3-hydroxy-8-methyldecanoic acid moiety contained stereogenic centers at C-12 and C-17. Initially, the modified Mosher's method was applied for the oxygen-bearing chiral center at C-12. However, multiple esterifying attempts at the hydroxy group by $S$ and $\mathrm{R}$-MTPA-Cl were not successful. Therefore, DP4 calculation was used to determine the absolute configurations. Four possible diastereomers of 3-hydroxy-8-methyldecanoic acid of svalbamide A (1), namely $\mathbf{1 a}(12 R$ and $17 R), \mathbf{1 b}(12 S$ and $17 R), \mathbf{1 c}(12 R$ and $17 S)$, and $1 \mathrm{~d}(12 S$ and $17 S)$, were constructed with the established $2 R$ and $6 R$ configurations (Figure 4). Following this, the ${ }^{1} \mathrm{H}$ and ${ }^{13} \mathrm{C}$ chemical shifts of 158 conformers were calculated and averaged with their Boltzmann populations. Our DP4 calculations, based on 
statistical comparisons of the calculated and experimental chemical shifts, indicated that the diastereomer $\mathbf{1 d}$ (12S and $17 S$ ) was suitable for svalbamide A (1) with $96.0 \%$ probability (Figure 4). The absolute configuration of svalbamide B (2) was subsequently proposed as $2 S, 6 R, 12 S$, and $17 S$.

Table 1. ${ }^{1} \mathrm{H}$ and ${ }^{13} \mathrm{C}$ NMR data for svalbamides A (1) and B (2) in DMSO- $d_{6}$.

\begin{tabular}{|c|c|c|c|c|c|}
\hline \multirow[b]{2}{*}{ Position } & & \multicolumn{2}{|c|}{ Svalbamide A (1) ${ }^{a}$} & \multicolumn{2}{|c|}{ Svalbamide B (2) ${ }^{a}$} \\
\hline & & $\delta_{\mathrm{C}}$, Type & $\begin{array}{l}\delta_{\mathrm{H},} \text { Mult } \\
(J \text { in Hz) }\end{array}$ & $\delta_{\mathrm{C}}$, Type & $\begin{array}{l}\delta_{\mathrm{H},} \text { Mult } \\
(J \text { in } \mathrm{Hz})\end{array}$ \\
\hline \multirow{6}{*}{ 3-amino-2-pyrrolidinone } & 1 & $174.2, \mathrm{C}$ & & $174.2, \mathrm{C}$ & \\
\hline & 2 & $49.4, \mathrm{CH}$ & $4.30, \mathrm{~m}$ & $49.5, \mathrm{CH}$ & $4.27, \mathrm{~m}$ \\
\hline & $3 a$ & 28.0, $\mathrm{CH}_{2}$ & $1.82, \mathrm{~m}$ & 28.3, $\mathrm{CH}_{2}$ & 1.76, $\mathrm{m}$ \\
\hline & $\begin{array}{c}3 \mathrm{~b} \\
4\end{array}$ & $38.0, \mathrm{CH}_{2}$ & $\begin{array}{l}2.26, \mathrm{~m} \\
3.16, \mathrm{~m}\end{array}$ & $38.0, \mathrm{CH}_{2}$ & $\begin{array}{l}2.29, \mathrm{~m} \\
3.16, \mathrm{~m}\end{array}$ \\
\hline & $4-\mathrm{TH}$ & & 7.78, br s & $50.0, \mathrm{Cl1}_{2}$ & 7.81 , br s \\
\hline & $\begin{array}{c}2-\mathrm{NH} \\
5\end{array}$ & 171.0, C & $8.10, \mathrm{~d}(8.5)$ & $171.0, \mathrm{C}$ & $8.21, \mathrm{~d}(8.5)$ \\
\hline \multirow{9}{*}{ D-Val } & 6 & $57.2, \mathrm{CH}$ & 4.18, dd & $57.2, \mathrm{CH}$ & $4.20, \mathrm{dd}$ \\
\hline & 7 & $30.7, \mathrm{CH}$ & $\begin{array}{l}(9.0,0.5) \\
1.96, \mathrm{~m}\end{array}$ & $30.6, \mathrm{CH}$ & $1.94, \mathrm{~m}$ \\
\hline & 8 & $18.0, \mathrm{CH}_{3}$ & $0.84, \mathrm{~d}(7.0)$ & $18.0, \mathrm{CH}_{3}$ & $0.83, \mathrm{~d}(7.0)$ \\
\hline & 9 & $19.3, \mathrm{CH}_{3}$ & $0.88, \mathrm{~d}(7.0)$ & $19.1, \mathrm{CH}_{3}$ & $0.84, \mathrm{~d}(7.0)$ \\
\hline & $\begin{array}{c}\text { 6-NH } \\
10\end{array}$ & $170.8, \mathrm{C}$ & $7.83, \mathrm{~d}(9.0)$ & $170.8, \mathrm{C}$ & $7.85, \mathrm{~d}(9.0)$ \\
\hline & $11 \mathrm{a}$ & $43.4, \mathrm{CH}_{2}$ & $\begin{array}{c}2.23, \mathrm{dd} \\
(14.0,7.0)\end{array}$ & $43.4, \mathrm{CH}_{2}$ & $\begin{array}{c}2.25, \mathrm{dd} \\
(14.0,7.0)\end{array}$ \\
\hline & $11 b$ & & $\begin{array}{c}2.29, \mathrm{dd} \\
(14.0,5.0)\end{array}$ & & \\
\hline & 12 & $67.5, \mathrm{CH}$ & $3.78, \mathrm{~m}$ & $67.6, \mathrm{CH}$ & $3.78, \mathrm{~m}$ \\
\hline & 13 & $36.7, \mathrm{CH}_{2}$ & $1.33, \mathrm{~m}^{\mathrm{b}}$ & $36.7, \mathrm{CH}_{2}$ & $1.33, \mathrm{~m}^{\mathrm{b}}$ \\
\hline \multirow[t]{10}{*}{ 3-hydroxy-8-methyldecanoic acid } & $14 a$ & $252 \mathrm{CH}_{2}$ & $1.24, \mathrm{~m}^{\mathrm{b}}$ & $252 \mathrm{CH}_{2}$ & $1.24, \mathrm{~m}^{\mathrm{b}}$ \\
\hline & $14 \mathrm{~b}$ & $25.2, \mathrm{CH}_{2}$ & $1.34, \mathrm{~m}^{\mathrm{b}}$ & $25.2, \mathrm{CH}_{2}$ & $1.34, \mathrm{~m}^{\mathrm{b}}$ \\
\hline & 15 & $26.5, \mathrm{CH}_{2}$ & $1.23, \mathrm{~m}^{\mathrm{b}}$ & $26.5, \mathrm{CH}_{2}$ & $1.23, \mathrm{~m}^{\mathrm{b}}$ \\
\hline & $16 a$ & $36.0, \mathrm{CH}_{2}$ & $1.05, \mathrm{~m}$ & $36.0, \mathrm{CH}_{2}$ & $1.05, \mathrm{~m}$ \\
\hline & $\begin{array}{c}16 b \\
17\end{array}$ & 33.7, CH & $\begin{array}{l}1.25, \mathrm{~m}^{\mathrm{b}} \\
1.28, \mathrm{~m}^{\mathrm{b}}\end{array}$ & $33.7, \mathrm{CH}$ & $\begin{array}{l}1.25, \mathrm{~m}^{\mathrm{b}} \\
1.28, \mathrm{~m}^{\mathrm{b}}\end{array}$ \\
\hline & $18 \mathrm{a}$ & $289 \mathrm{CH}$ & $1.09, \mathrm{~m}$ & $289 \mathrm{CH}$ & $1.09, \mathrm{~m}$ \\
\hline & $18 \mathrm{~b}$ & $28.9, \mathrm{CH}_{2}$ & $1.28, \mathrm{~m}^{\mathrm{b}}$ & $28.9, \mathrm{CH}_{2}$ & $1.28, \mathrm{~m}^{\mathrm{b}}$ \\
\hline & 19 & $11.2, \mathrm{CH}_{3}$ & $0.82, \mathrm{t}(7.0)$ & $11.2, \mathrm{CH}_{3}$ & $0.83, \mathrm{t}(7.0)$ \\
\hline & 20 & $19.1, \mathrm{CH}_{3}$ & $0.81, \mathrm{~d}(6.5)$ & $19.1, \mathrm{CH}_{3}$ & $0.81, \mathrm{~d}(6.5)$ \\
\hline & $12-\mathrm{OH}$ & & $4.65, \mathrm{~d}(5.0)$ & & $4.67, \mathrm{~d}(5.0)$ \\
\hline
\end{tabular}

${ }^{\mathrm{a} 1} \mathrm{H}$ and ${ }^{13} \mathrm{C}$ NMR data were recorded at 800 and $200 \mathrm{MHz}$, respectively. ${ }^{\mathrm{b}}$ Overlapping signals.
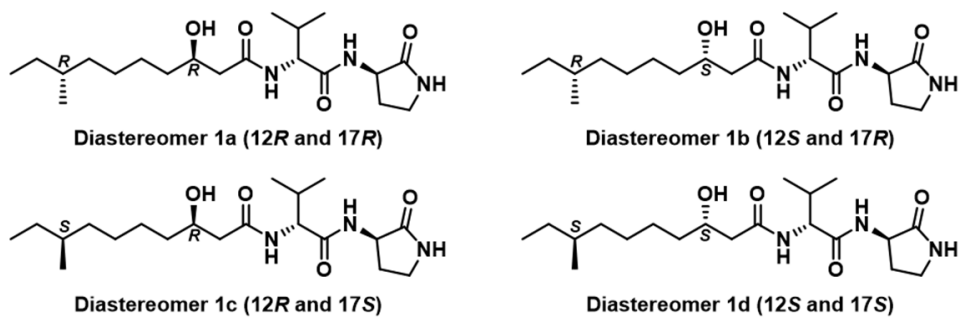

$$
\text { DP4 Calculation result }
$$

Both carbon and proton data : Diastereomer $1 \mathrm{a}(12 R$ and $17 R)-0 \%$ Diastereomer $1 \mathrm{~b}(12 \mathrm{~S}$ and $17 R)-4 \%$ Diastereomer $1 \mathrm{c}(12 R$ and $17 S)-0 \%$ Diastereomer $1 \mathrm{~d}(12 S$ and $17 S)-96 \%$

Figure 4. The simulated models of the four possible diastereomers (a-d) of svalbamide A (1) and the results of DP4 calculations.

\subsection{Biological Evaluation}

The biological activities of svalbamides A (1) and B (2) were evaluated in several ways. First, we measured cytotoxicity against various cancer cell lines [5], including HCT116 (human colorectal cancer cells), MDA-MB-231 (human breast cancer cells), A549 (human 
lung cancer cells), SK-HEP-1 (human liver cancer cells), and SNU-638 (human gastric cancer cells), but 1 and 2 showed no significant cytotoxicity against the tested cell lines even at $50 \mu \mathrm{M}$. Therefore, we evaluated the detoxification ability by measuring quinone reductase (QR) activity. QR is a major phase II detoxification enzyme, and the induction of QR activity is considered as a strategy to increase the chemoprevention effect. Svalbamide A (1) enhanced QR activity by 1.45-, 1.98-, and 2.54-fold at 10, 20, and $40 \mu \mathrm{M}$, respectively, in a concentration-dependent manner. In addition, svalbamide B (2) effectively induced QR activity by 1.93-, 2.64-, and 2.98-fold at 10, 20, and $40 \mu \mathrm{M}$, respectively (Figure 5). At a concentration of $40 \mu \mathrm{M}$, it exhibited a comparable level of QR activity induction in the positive control of $1 \mu \mathrm{M} \beta$-naphthoflavone $(\beta-N F)$. These results suggest that 1 and 2 are potential chemotypes with chemopreventive activity.
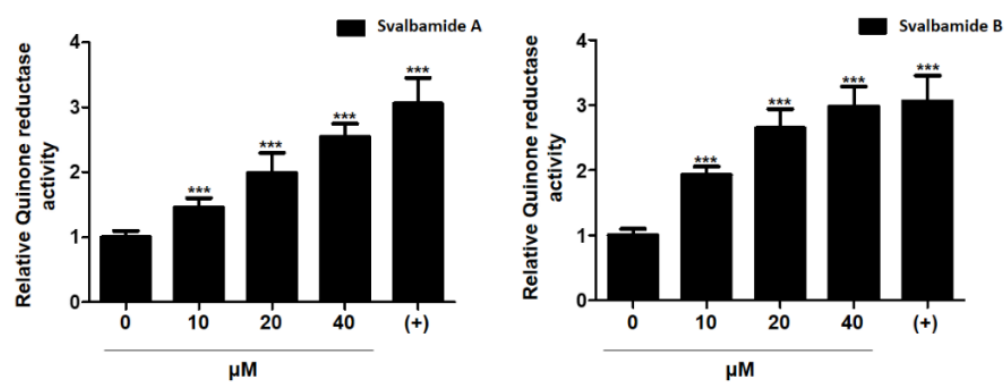

Figure 5. Induction of quinone reductase activity by svalbamide A (1) and B (2). Svalbamide A (1) and B (2) showed QR induction activity, with 2.54- and 2.98-fold increases, respectively, at $40 \mu \mathrm{M}$. All data represent the mean $\pm \mathrm{SD}(n=3)$. ${ }^{* * *} p<0.001$ compared to the control.

\section{Materials and Methods}

\subsection{General Experimental Procedures}

Optical rotations were measured using a JASCO P-2000 polarimeter (sodium light source, JASCO, Easton, PA, USA) with a $1 \mathrm{~cm}$ cell. IR spectra were obtained using a Thermo NICOLET iS10 spectrometer (Thermo, Madison, CT, USA). ${ }^{1} \mathrm{H},{ }^{13} \mathrm{C}$, and 2D NMR spectra were recorded on a Bruker Avance $800 \mathrm{MHz}$ spectrometer (Bruker, Billerica, MA, USA) at the Research Institute of Pharmaceutical Sciences, Seoul National University. ESI low-resolution LC/MS data were recorded using an Agilent Technologies 6130 Quadrupole mass spectrometer (Agilent Technologies, Santa Clara, CA, USA) coupled with an Agilent Technologies 1200 series high-performance liquid chromatography (HPLC) instrument using a reversed-phase $\mathrm{C}_{18}(2)$ column (Phenomenex Luna, $100 \times 4.6 \mathrm{~mm}$ ). HR-ESI mass spectra were acquired on a high-resolution LC/MS-MS spectrometer (Q-TOF 5600) at the National Instrumentation Center for Environmental Management (NICEM) in the College of Agriculture and Life Sciences at Seoul National University.

\subsection{Isolation, Cultivation, Phylogenetic Analysis, and Extraction of Bacteria}

During the Korea-Norway Joint marine-geoscientific cruise with RV Helmer Hanssen to North Spitsbergen in 2017, a sediment core (HH17-1085) was taken at a water depth of $322 \mathrm{~m}$ with a giant box corer from the continental shelf off Wijdefjorden $\left(80^{\circ} 16.469^{\prime}\right.$ $\mathrm{N}, 016^{\circ} 12.625^{\prime} \mathrm{E}$ ) in Svalbard (Figure 6). Surface sediment corresponding to $1 \mathrm{~cm}$ depth was collected from core HH17-1085. A portion of the sample $(2 \mathrm{~g})$ was diluted in $20 \mathrm{~mL}$ sterilized water and vortexed. The mixture was spread on YEME isolation solid medium (500 mL of sterilized water, $9 \mathrm{~g}$ agar, $100 \mathrm{mg}$ cycloheximide, $2 \mathrm{~g}$ yeast, $5 \mathrm{~g}$ malt, and $2 \mathrm{~g}$ glucose) for two weeks. Strain SVB7 was isolated in YEME medium after one week of incubation for further study.

The 16S rRNA gene sequence of strain SVB7 was obtained by Sanger sequencing using PCR products amplified with the universal primers $27 \mathrm{~F}$ and 1492R. The resultant $16 \mathrm{~S}$ rRNA gene sequence (1440 bp) was queried in a BLASTn search implemented at GenBank and was also identified by the "16S-based ID service" in the EzbioCloud database [6]. For phylogenetic analysis, sequences of strain SVB7 and its close relatives retrieved from the 
EzBioCloud database were aligned with the SINA online aligner [7]. Using the aligned sequences, phylogenetic trees were inferred by maximum likelihood, neighbor-joining, and minimum-evolution algorithms implemented in MEGA software version 7.0 [8].

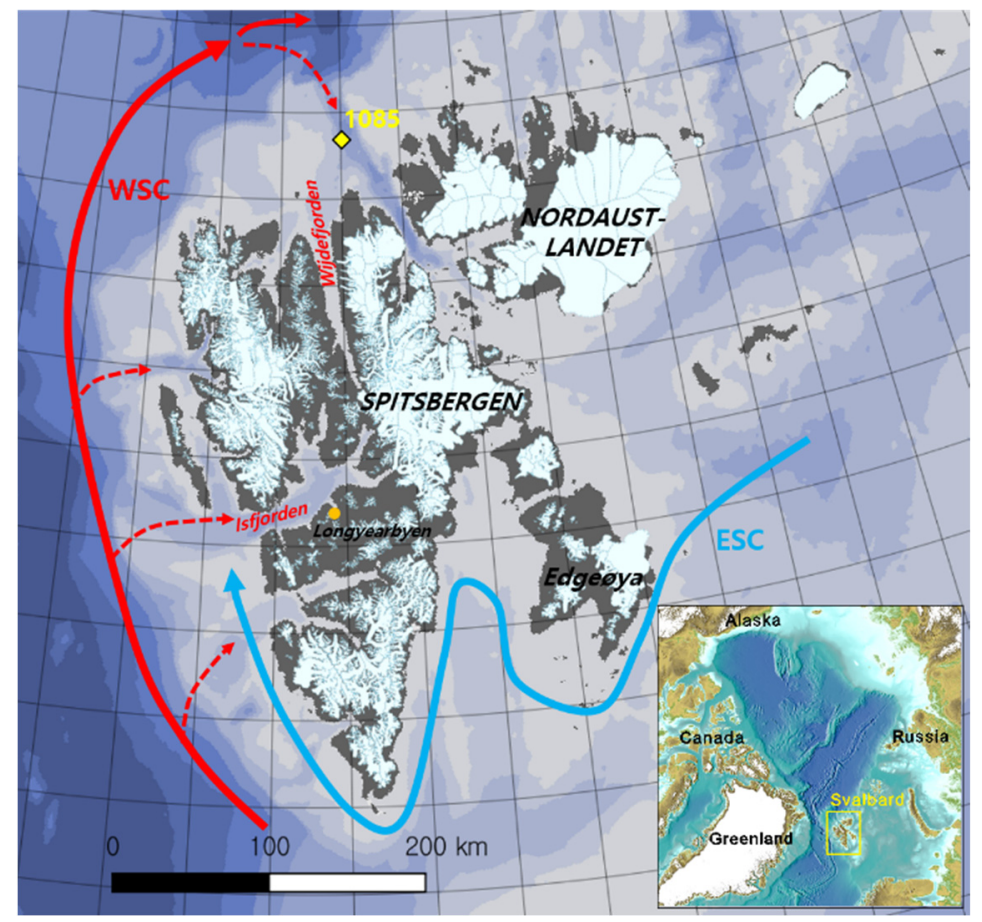

Figure 6. Map of the Svalbard archipelago with the core site and the main currents influencing Svalbard highlighted. The red and blue arrows indicate the West Spitsbergen Current (WSC) and East Spitsbergen Current (ESC), respectively, and the yellow rectangle indicates the coring site (HH171085-GC). The shaded white color represents the present glacier-covered areas on the archipelago.

The SVB7 strain was cultured in $50 \mathrm{~mL}$ modified $\mathrm{K}$ medium $(4 \mathrm{~g}$ yeast extract, $5 \mathrm{~g}$ malt extract, $5 \mathrm{~g}$ soytone, $5 \mathrm{~g}$ soluble starch, $5 \mathrm{~g}$ mannitol, $2 \mathrm{~g}$ glucose, and $6 \mathrm{~g}$ glycerol in $1 \mathrm{~L}$ deionized water) in a $125 \mathrm{~mL}$ Erlenmeyer flask. After cultivation for 2 days on a rotary shaker at $200 \mathrm{rpm}$ and $30^{\circ} \mathrm{C}, 5 \mathrm{~mL}$ of the culture medium was inoculated in $200 \mathrm{~mL}$ of modified $\mathrm{K}$ medium in a $500 \mathrm{~mL}$ Erlenmeyer flask. After cultivation for 2 days under the same incubation conditions, $10 \mathrm{~mL}$ of the culture medium was inoculated in $1 \mathrm{~L}$ of modified K medium in $2.8 \mathrm{~L}$ Fernbach flasks $(200$ ea $\times 1 \mathrm{~L})$ at $170 \mathrm{rpm}$ and $30{ }^{\circ} \mathrm{C}$ for 6 days. The whole culture of SVB7 was extracted with $300 \mathrm{~L}$ of EtOAc. The EtOAc and water layers were separated, and the remaining water in the EtOAc layer was removed by adding anhydrous sodium sulfate. The extract was concentrated using a rotary evaporator, yielding $50 \mathrm{~g}$ of dry material.

\subsection{Isolation of Svalbamides $A$ and $B$}

The crude extract was divided into ten equal parts and fractioned over a $\mathrm{C}_{18}$ reversedphase open column $(\phi 6.5 \times 10 \mathrm{~cm})$ with $500 \mathrm{~mL}$ of $20 \%, 40 \%, 60 \%, 80 \%$, and $100 \%$ $\mathrm{MeOH}-\mathrm{H}_{2} \mathrm{O}$. The $80 \% \mathrm{MeOH}$ fraction was subjected to a reversed-phase HPLC (Kromasil $\mathrm{C}_{18}, 5 \mu \mathrm{m}, 250 \times 10 \mathrm{~mm}$, flow rate $=2 \mathrm{~mL} / \mathrm{min}$ ) using a gradient solvent system from $35 \%$ to $75 \% \mathrm{CH}_{3} \mathrm{CN}-\mathrm{H}_{2} \mathrm{O}$ over 40 min with $210 \mathrm{~nm}$ UV detection. Svalbamides A and $\mathrm{B}$ were collected as one broad peak at $25 \mathrm{~min}$. The recorded ${ }^{1} \mathrm{H}$ NMR spectra of the peak indicated a diastereomeric mixture, prompting further purification on a chiral HPLC column (CHIRALPAK IB, $5 \mu \mathrm{m}, 250 \times 4.6 \mathrm{~mm}$, flow rate $=0.6 \mathrm{~mL} / \mathrm{min}$ ) using a step gradient $45 \% \mathrm{CH}_{3} \mathrm{CN}$ isocratic solvent system over $10 \mathrm{~min}$, followed by a $60 \% \mathrm{CH}_{3} \mathrm{CN}-$ $\mathrm{H}_{2} \mathrm{O}$ isocratic solvent system from 10 to $50 \mathrm{~min}$. Svalbamides A $(10.0 \mathrm{mg})$ and $\mathrm{B}(7.8 \mathrm{mg})$ were isolated at 30 and $31.5 \mathrm{~min}$, respectively. 
Svalbamide A (1): white powder; $[\alpha] 20 D+19.5$ (c 0.1, MeOH); IR (neat) $v_{\max } 3289$, 2926,1632 $\mathrm{cm}^{-1} ;{ }^{1} \mathrm{H}$ and ${ }^{13} \mathrm{C}$ NMR (800 MHz, DMSO-d ${ }_{6}$ ) (Table 1); HR-ESI-MS $m / z$ : $[\mathrm{M}+\mathrm{H}]^{+}$Calcd for $\mathrm{C}_{20} \mathrm{H}_{38} \mathrm{~N}_{3} \mathrm{O}_{4}, 384.2857$, found 384.2851.

Svalbamide B (2): white powder; $[\alpha] 20 D+25.2$ (c 0.1, MeOH); IR (neat) $v_{\max } 3276,2928$, $1612 \mathrm{~cm}^{-1} ;{ }^{1} \mathrm{H}$ and ${ }^{13} \mathrm{C}$ NMR (800 MHz, DMSO- $d_{6}$ ) (Table 1); HR-ESI-MS m/z: [M + H] ${ }^{+}$ Calcd for $\mathrm{C}_{20} \mathrm{H}_{38} \mathrm{~N}_{3} \mathrm{O}_{4}, 384.2857$, found 384.2845.

\subsection{Conformational Search and DP4 Analysis}

A conformational search was carried out using a mixed sampling method of torsional/ low-mode using MacroModel (version 9.9, Schrödinger LLC) in the Maestro suite (version 9.9, Schrödinger LLC). A total of 158 conformers of the diastereomers were identified with relative potential energies below $10 \mathrm{~kJ} / \mathrm{mol}$ using the MMFF force field. The shielding tensor values of the optimized conformers were calculated based on the equation below, where $\delta_{\text {calc }}^{x}$ is the calculated NMR chemical shift for nucleus $x$, and $\sigma^{\mathrm{o}}$ is the shielding tensor for the proton and carbon nuclei calculated at the B3LYP/6-31++ level. These values were averaged via the Boltzmann population with the associated Gibbs free energy and utilized for the DP4 analysis, which was facilitated using an Excel spreadsheet provided by the authors of [9] and as described in their publication.

$$
\delta_{\text {calc }}^{x}=\frac{\sigma^{\circ}-\sigma^{x}}{1-\sigma^{\circ} / 10^{6}}
$$

\subsection{Quinone Reductase Assay}

Hepa1c1c7 murine hepatoma cells (American Type Culture Collection, Manassas, VA, USA) were used to investigate QR induction activity. The test cells were seeded $\left(3 \times 10^{4}\right.$ cells $\left./ \mathrm{mL}\right)$ and incubated at $37^{\circ} \mathrm{C}$ for $24 \mathrm{~h}$ with $5 \% \mathrm{CO}_{2}$ containing humidified atmosphere. The plates were then exposed to svalbamides $A$ and $B(\mathbf{1}, \mathbf{2})$, including a positive control compound, $\beta$-naphthoflavone $(\beta$-NF). After $24 \mathrm{~h}$, the media were decanted from the wells, and the cells in each well were lysed by incubation at $37{ }^{\circ} \mathrm{C}$ with $250 \mu \mathrm{L}$ of a mixed solution consisting of $10 \mathrm{mM}$ Tris- $\mathrm{HCl} \mathrm{pH} 8.0,140 \mathrm{mM} \mathrm{NaCl}, 15 \mathrm{mM} \mathrm{MgCl}$, and $0.5 \%$ NP-40 (IGEPAL CA-630, Sigma, St. Louis, MO, USA) for $10 \mathrm{~min}$. A $1 \mathrm{~mL}$ aliquot of the complete reaction mixture $(12.5 \mathrm{mM}$ Tris $-\mathrm{HCl} \mathrm{pH} 7.4,0.67 \mathrm{mg} / \mathrm{mL}$ bovine serum albumin (BSA), 0.01\% Tween-20, $50 \mu \mathrm{M}$ flavin adenine dinucleotide (FAD), $1 \mathrm{mM}$ glucose6-phosphate, $2 \mathrm{U} / \mathrm{mL}$ glucose-6-phosphate dehydrogenase, $30 \mu \mathrm{M}$ NADP, $50 \mu \mathrm{g} / \mathrm{mL}$ 3(4,5-dimethylthiazo-2-yl)-2,5-diphenyltetrazolium bromide (MTT), and $50 \mu \mathrm{M}$ menadione) was added to each of the wells, and the plates were incubated at $25{ }^{\circ} \mathrm{C}$ for the colorimetric reaction. The rate of NADPH-dependent menadiol-mediated reduction of MTT in this reaction was measured at $610 \mathrm{~nm}$, and cytotoxicity was determined by crystal violet staining of an identical set of the test plates. The quinone reductase activity was calculated from the following equation: absorbance change for MTT per min/absorbance of crystal violet $\times$ $3345 \mathrm{nmol} / \mathrm{mg}$. The value of $3345 \mathrm{nmol} / \mathrm{mg}$ represents the ratio of the extinction coefficient of MTT and the proportionality constant of crystal violet. The relative QR activity was normalized using controls [10].

\section{Conclusions}

Our chemical study of the Arctic sediment-derived Paenibacillus sp. SVB7 led to the discovery and structural elucidation of two new pyrrolidinone-bearing lipodipeptides, svalbamides A (1) and B (2), in which QR activity could be induced. Based on spectroscopic analysis, advanced Marfey's analysis, and DP4 calculation, these two compounds were identified to have a diastereomeric relationship with alternative absolute configurations at the 3-amino-2-pyrrolidione unit. Svalbamides A and B are structurally unique as they contain 3-amino-2- pyrrolidinone amino acid. This amino acid unit was rarely reported in natural products, with the only example being of actinoramide E, an antimalarial peptide from a marine-derived Streptomyces strain [11]. 3-Hydroxy-8-methyldecanoic acid 
is another interesting component. This saturated fatty acid was occasionally found in natural products from Paenibacillus and related bacteria. For example, tridecaptins A-C were first isolated from Bacillus polymyxa in 1978 and were studied in various fields, with reports of new derivatives and biosynthesis undertaken to date [12]. A series of new tridecaptin compounds containing 3-hydroxy-8-methyldecanoic acid were discovered in a Paenibacillus strain collected in the deep oligotrophic Krubera-Voronja cave. However, the absolute configuration of this fatty acid was not determined [13-15]. Octapeptin and cerexin from the Bacillus sp. bear the same fatty acid, but no experiments have yet been conducted to reveal the absolute stereochemistry $[16,17]$. Therefore, svalbamides A and B are the first metabolites for which the stereochemistry of 3-hydroxy-8-methyldecanoic acid was addressed. Discovering these new bioactive secondary metabolites from Paenibacillus from the polar region indicates that chemical studies of underinvestigated bacterial taxa in marine extreme habitats, such as the Arctic Ocean, could lead to the discovery of significant natural chemical diversity with pharmaceutical potential in terms of drug discovery.

Supplementary Materials: The following are available online at https:/ /www.mdpi.com/article/ 10.3390/md19040229/s1, Figure S1. ${ }^{1} \mathrm{H}$ NMR spectrum (800 MHz) of svalbamide A (1) in DMSO$d_{6}$., Table S1: LC/MS analysis of D- and L-FDAA derivatives of the amino acid-derived units in svalbamide A (1), svalbamide B (2), L-2,4-diamino butanoic acid (3), D-valine (4) and L-valine (5) authentic samples. Retention times (min) are notified., Figure S2. ${ }^{13} \mathrm{C}$ NMR spectrum $(200 \mathrm{MHz})$ of svalbamide A (1) in DMSO- $d_{6}$, Figure S3. COSY NMR spectrum $(800 \mathrm{MHz})$ of svalbamide A (1) in DMSO- $d_{6}$, Figure S4. HSQC NMR spectrum (800 MHz) of svalbamide A (1) in DMSO- $d_{6}$, Figure S5. HMBC NMR spectrum ( $800 \mathrm{MHz}$ ) of svalbamide A (1) in DMSO- $d_{6}$, Figure S6. TOCSY NMR spectrum $(800 \mathrm{MHz})$ of svalbamide A (1) in DMSO- $d_{6}$, Figure $57 .{ }^{1} \mathrm{H}$ NMR spectrum $(800 \mathrm{MHz})$ of svalbamide B (2) in DMSO- $d_{6}$, Figure $58 .{ }^{13} \mathrm{C}$ NMR spectrum (200 MHz) of svalbamide B (2) in DMSO- $d_{6}$, Figure S9. COSY NMR spectrum (800 MHz) of svalbamide B (2) in DMSO- $d_{6}$, Figure S10. HSQC NMR spectrum ( $800 \mathrm{MHz}$ ) of svalbamide B (2) in DMSO- $d_{6}$, Figure S11. HMBC NMR spectrum $(800 \mathrm{MHz})$ of svalbamide B (2) in DMSO- $d_{6}$, Figure S12. TOCSY NMR spectrum $(800 \mathrm{MHz})$ of svalbamide B (2) in DMSO- $d_{6}$, Figure S13. The simulated models of four possible diastereomers (a-d) of svalbamide A (1) and the result of DP4 calculation, Table S1. LC/MS analysis of D- and L-FDAA derivatives of the amino acid-derived units in svalbamide A (1), svalbamide B (2) and L-2,4-diamino butanoic acid authentic sample (3), D-valine (4) and L-valine (5). Retention times (min) are notified, Table S2. The major conformers of diastereomers (a-d) of svalbamide A (1), identified by conformational searches in MMFF94 force field using MacroModel, Table S3. Experimental (Exp.) and calculated (Cal.) chemical shift values (CS, $\delta$ ) of diastereomers (a-d) of $\mathbf{1}$ and svalbamide A (1).

Author Contributions: Conceptualization, D.-C.O. and Y.E.D.; methodology, D.-C.O., J.S., J.-C.C. and S.K.L.; software, Y.L., Y.E.D. and E.S.B.; validation Y.E.D. and E.S.B.; formal analysis, D.-C.O., Y.E.D., E.S.B., Y.L. and J.-C.C.; investigation, Y.E.D., D.-C.O., S.-I.N., E.S.B., Y.L., J.-C.C., S.-J.N. and S.K.L.; resources, S.-I.N. and D.-C.O.; data curation, Y.E.D., E.S.B., Y.L., J.-C.C., S.K.L. and D.-C.O.; writingoriginal draft preparation, D.-C.O., Y.E.D., E.S.B., Y.L., J.-C.C., S.K.L. and S.-I.N.; writing-review and editing, D.-C.O., Y.E.D., S.-J.N., S.-I.N. and J.S.; visualization, D.-C.O., Y.E.D., E.S.B., Y.L., S.K.L. and J.-C.C.; supervision, D.-C.O.; project administration, D.-C.O., Y.E.D.; funding acquisition, D.-C.O., S.-J.N. and S.-I.N. All authors have read and agreed to the published version of the manuscript.

Funding: This work was supported by the Collaborative Genome Program of the Korea Institute of Marine Science and Technology Promotion (KIMST) funded by the Ministry of Oceans and Fisheries (MOF) (No. 20180430) and the National Research Foundation of Korea (NRF) grants funded by the Ministry of Science and ICT (MSIT) (2021R1A4A2001251) and partly by the Basic Core Technology Development Program for the Oceans and the Polar Regions (NRF-2015M1A5A1037243).

Institutional Review Board Statement: Not applicable.

Data Availability Statement: All data is contained within this article and Supplementary Materials.

Acknowledgments: The captains and crews of R/V Helmer Hanssen, Matthias Forwick (UiT, Norway), and the cruise participants all supported the core sampling during the cruise in 2017.

Conflicts of Interest: The authors declare no conflict of interest. 


\section{References}

1. Carroll, A.R.; Copp, B.R.; Davis, R.A.; Keyzers, R.A.; Prinsep, M.R. Marine natural products. Nat. Prod. Rep. 2021, $38,362-413$. [CrossRef] [PubMed]

2. $\quad$ Bae, M.; An, J.S.; Bae, E.S.; Oh, J.; Park, S.H.; Lim, Y.; Ban, Y.H.; Kwon, Y.; Cho, J.-C.; Yoon, Y.J.; et al. Donghaesulfins A and B, dimeric benz $[a]$ anthracene thioethers from volcanic island derived Streptomyces sp. Org. Lett. 2019, 21, 3635-3639. [CrossRef] [PubMed]

3. Bae, M.; An, J.S.; Hong, S.-H.; Bae, E.S.; Chung, B.; Kwon, Y.; Hong, S.; Oh, K.-B.; Shin, J.; Lee, S.K.; et al. Donghaecyclinones A-C: New cytotoxic rearranged angucyclinones from a volcanic island-derived marine Streptomyces sp. Mar. Drugs 2020, 18, 121. [CrossRef] [PubMed]

4. Moon, K.; Ahn, C.-H.; Shin, Y.; Won, T.H.; Ko, K.; Lee, S.K.; Oh, K.-B.; Shin, J.; Nam, S.-I.; Oh, D.-C. New benzoxazine secondary metabolites from an arctic actinomycete. Mar. Drugs 2014, 12, 2526-2538. [CrossRef] [PubMed]

5. Kim, W.K.; Bach, D.-H.; Ryu, H.W.; Oh, J.; Park, H.J.; Hong, J.-Y.; Song, H.-H.; Eum, S.; Bach, T.T.; Lee, S.K. Cytotoxic activities of Telectadium dongnaiense and its constituents by inhibition of the Wnt/ $\beta$-catenin signaling pathway. Phytomedicine 2017, 34, 136-142. [CrossRef] [PubMed]

6. Yoon, S.-H.; Ha, S.-M.; Kwon, S.; Lim, J.; Kim, Y.; Seo, H.; Chun, J. Introducing EzBioCloud: A taxonomically united database of 16S rRNA gene sequences and whole-genome assemblies. Int. J. Syst. Evol. Microbiol. 2017, 67, 1613-1617. [CrossRef] [PubMed]

7. Pruesse, E.; Peplies, J.; Glöckner, F.O. SINA: Accurate high-throughput multiple sequence alignment of ribosomal RNA genes. Bioinformatics 2012, 28, 1823-1829. [CrossRef] [PubMed]

8. Kumar, S.; Stecher, G.; Tamura, K. MEGA7: Molecular evolutionary genetics analysis version 7.0 for bigger datasets. Mol. Biol. Evol. 2016, 33, 1870-1874. [CrossRef] [PubMed]

9. An, J.S.; Lee, J.Y.; Kim, E.; Ahn, H.; Jang, Y.-J.; Shin, B.; Hwang, S.; Shin, J.; Yoon, Y.J.; Lee, S.K.; et al. Formicolides A and B, antioxidative and antiangiogenic 20-membered macrolides from a wood ant gut bacterium. J. Nat. Prod. 2020, 83, 2776-2784. [CrossRef] [PubMed]

10. Cuendet, M.; Oteham, C.P.; Moon, R.C.; Pezzuto, J.M. Quinone reductase induction as a biomarker for cancer chemoprevention. J. Nat. Prod. 2006, 69, 460-463. [CrossRef] [PubMed]

11. Cheng, K.C.-C.; Cao, S.; Raveh, A.; MacArthur, R.; Dranchak, P.; Chlipala, G.; Okoneski, M.T.; Guha, R.; Eastman, R.T.; Yuan, J.; et al. Actinoramide A identified as a potent antimalarial from titration-based screening of marine natural product extracts. J. Nat. Prod. 2015, 78, 2411-2422. [CrossRef] [PubMed]

12. Shoji, J.I.; Hinoo, H.; Sakazaki, R.; Kato, T.; Wakisaka, Y.; Mayama, M.; Matsuura, S.; Miwa, H. Isolation of tridecaptins A, B and C studies on antibiotics from the genus Bacillus. XXIII. J. Antibiot. 1978, 31, 646-651. [CrossRef] [PubMed]

13. Lebedeva, J.; Jukneviciute, G.; Čepaite, R.; Vickackaite, V.; Pranckutè, R.; Kuisiene, N. Genome mining and characterization of biosynthetic gene clusters in two cave strains of Paenibacillus sp. Front. Microbiol. 2021, 11, 3433. [CrossRef] [PubMed]

14. Bann, S.J.; Ballantine, R.D.; Cochrane, S.A. The tridecaptins: Non-ribosomal peptides that selectively target Gram-negative bacteria. RSC Med. Chem. 2021. [CrossRef]

15. Cochrane, S.A.; Lohans, C.T.; van Belkum, M.J.; Bels, M.A.; Vederas, J.C. Studies on tridecaptin B1, a lipopeptide with activity against multidrug resistant gram-negative bacteria. Org. Biomol. Chem. 2015, 13, 6073-6081. [CrossRef] [PubMed]

16. Kato, T.; Shoji, J.I. The structure of octapeptin D studies on antibiotics from the genus Bacillus. XXVIII. J. Antibiot. 1980, 33, 186-191. [CrossRef] [PubMed]

17. Shoji, J.I.; Kato, T.; Terabe, S.; Konaka, R. Resolution of peptide antibiotics, cerexins and tridecaptins, by high performance liquid chromatography studies on antibiotics from the genus Bacillus. XXVI. J. Antibiot. 1979, 32, 313-319. [CrossRef] [PubMed] 